\title{
Improvement of an HPLC method to determine urinary $\delta$-aminolevulinic acid
}

\section{Aprimoramento de um método de HPLC para determinar ácido $\delta$-aminolevulínico urinário}

Atecla Nunciata Lopes Alves'; Nairo Massakazu Sumita²; Alexandre Soriano Fortini; Maurilio Pacheco Neto ; Maria Elizabete Mendes ${ }^{5}$; Alberto José da Silva Duarte ${ }^{6}$

\begin{tabular}{l}
\multicolumn{1}{c}{ unitermos } \\
Urinary $\delta$-aminolevulinic \\
acid \\
High performance liquid \\
chromatography \\
Acute porphyrias
\end{tabular}

\section{abstract}

Objective: The purpose of this study was to evaluate and improve a high performance liquid chromatography (HPLC) methodology to determine urinary $\delta$-aminolevulinic acid (ALA-U) with small volumes of sample. Method: The method was based on the formation of a fluorescent compound and subsequent 15-minute chromatographic run. Results: The method shows suitable linearity, precision and recovery. Urine samples showed $1.2 \pm 0.9 \mathrm{mg} / \mathrm{I}$ (media \pm standard deviation) of ALA-U. Conclusion: The method was considered suitable for the routine analysis of ALA-U.

\section{resumo}

Introdução e objetivo: A proposta deste estudo foi avaliar e aprimorar uma metodologia de cromatografia líquida de alta eficiência (CLAE) ${ }^{(11,12)}$, a fim de determinar o ácido $\delta$-aminolevulínico urinário (ALA-U) utilizando volumes reduzidos de amostra. Método: O método baseia-se na formação de um composto fluorescente e posterior corrida cromatográfica de 15 minutos. Resultados: 0 método apresentou linearidade, precisão e recuperação adequadas. Os resultados para as amostras de urina testadas foram 1,2 \pm 0,9 mg/l (média \pm desvio padrão) de ALA-U. Conclusão: O método foi considerado adequado para análises de rotina de ALA-U. key words

Ácido $\delta$-aminolevulínico urinário

Cromatografia líquida de alta eficiência

Porfirias agudas

\footnotetext{
1. Doutora; farmacêutica pesquisadora do Serviç̧o de Bioquímica Clínica da Divisão de Laboratório Central (DLC), Laboratório de Investigação Médica 03 (LIM 03) do Hospital das Clínicas (HC) da Faculdade de Medicina da Universidade de São Paulo (FMUSP).

2. Doutor; professor assistente da disciplina de Patologia Clínica; diretor do Serviço de Bioquímica Clínica da DLC-LIM 03-HCFMUSP.

3. Especialista em Patologia Clínica; médico assistente do Serviço de Bioquímica Clínica da DLC-LIM 03-HCFMUSP.

4. Mestrando; farmacêutico pesquisador do Serviço de Bioquímica Clínica da DLC-LIM 03-HCFMUSP.

5. Doutora; médica chefe do Serviço de Bioquímica Clínica da DLC-LIM 03-HCFMUSP.

6. Professor titular da disciplina de Patologia Clínica da FMUSP; diretor técnico de Divisão de Saúde da DLC-LIM 03-HCFMUSP.
} 


\section{Introduction and objective}

Aminolevulinic acid or $\delta$-aminolevulinic (ALA) is the first metabolite of the heme biosynthetic pathway. Enzymatic disturbances like inhibition of porphobilinogen desaminase and ALA-desidratase occur in intermittent porphyria (AIP), tyrosinemia ${ }^{(4)}$ and environmental or occupational lead $(\mathrm{Pb})$ exposure ${ }^{(4)}$, respectively. These conditions increase ALA levels with formation of enol and reactive oxygen species, which are inductors of serious hepatic and neurological damage ${ }^{(4)}$. In all these cases, the accumulation of ALA in blood and other tissues (mainly liver and brain) reflects an increase of urinary ALA (ALA-U) levels ${ }^{(4)}$. The quantification of ALA-U is useful to detect AIP in patients with symptoms as well as their asymptomatic relatives, and also monitor individuals in remission of AIP(8). ALA-U levels are used in biological monitoring of $\mathrm{Pb}$ exposure because show good correlation with blood $\mathrm{Pb}$ levels $(1,3,11)$.

Although colorimetric methods are used to quantify ALA-U, the sensibility and specificity of chromatographic methods with fluorescence detection are well known ${ }^{(7)}$. Analytical methods that can detect slight alterations of ALA-U are crucial for preventive actions in cases where metabolic alterations are still reversible ${ }^{(1)}$.

Our study is based on the high performance liquid chromatography (HPLC) fluorometry procedure of Tomokuni et al. ${ }^{(12)}$ and Oishi et al.(11) with regard to analytical conditions. We propose modifications in the procedure in order to use smaller volumes, maintaining the same performance with respect to sensibility and specificity.

\section{Material and method}

\section{Reagents}

ALA hydrochloride was purchased from Sigma Co. (St. Louis, MO, USA). Methanol and acetyl acetone were obtained from Merck (Darmstadt, Germany). Acetyl acetone reagent was prepared by mixing and homogenizing $1.9 \mathrm{ml}$ of acetyl acetone, $1.25 \mathrm{ml}$ of ethanol, and $9.4 \mathrm{ml}$ of water. Formaldehyde solution (10\%) was made by a 3.7 -fold dilution of the chemical reagent (37\%). All the reagents were analytical grade, prepared on the day of use and stored in the dark. Stock solution of ALA $(1,000 \mathrm{mg} / \mathrm{l})$ was prepared by dissolving ALA in water and storing it above $-8^{\circ} \mathrm{C}$ in the dark. This stock solution was diluted with pooled urine to give appropriate concentrations of ALA for the tests of validation described.

\section{Spiked samples}

For the method optimization and validation, samples of five healthy volunteers were mixed and the concentration of ALA background was determined. Then, that pooled urine was spiked and diluted to give the concentrations from 0.02 to $9.6 \mathrm{mg} / \mathrm{l}$ as described in results.

\section{Real samples}

Twenty urine specimens were collected early morning in polypropylene flasks protected from light, according to standard techniques, and kept in refrigerator $\left(2-8^{\circ} \mathrm{C}\right)$ until the analysis were performed in a maximum of 24 hours after collection. The urine samples were obtained from individuals not exposed to $\mathrm{Pb}$ and without diagnostic of acute porphyria in the Central Laboratory of the Clinics Hospital of São Paulo University, Brazil. The individuals aged between 11 and 68 years, and the collection occurred from 2007 to 2008. The concentration-dilution of spot urine sample was adjusted with the values of urinary creatinine. The Laboratory Ethics Committees approved the study.

\section{Procedure and apparatus}

The derivatization was based on a modification of the Hantzsch reaction, in which amine compounds react with acetyl acetone and formaldehyde. The reaction: $0.8 \mathrm{ml}$ of reagent of acetyl acetone, $25 \mu \mathrm{l}$ of the urine sample, and $0.1 \mathrm{ml}$ of $10 \%$ formaldehyde solution was done in a $1.5 \mathrm{ml}$ vial, mixed and heated for 10 minutes at $100^{\circ} \mathrm{C}$, cooled in an ice bath for 10 minutes and kept in the dark until analysis.

The HPLC from Shimadzu Co. (Kyoto, Japan) equipped with two pumps LC-10AD, automatic injector SIL-10 A, oven column CTO-10, fluorescence monitor (RF-535), and software LC solution was used. The column was a reversed-phase Inertsil ODS-3 (particle-size 5 um; $150 \times$ $4.6 \mathrm{~mm}$ ), oven $40^{\circ} \mathrm{C}$ and isocratic elution with methanol and water-acetic acid (500:500:10, $v / v / v)$ at a flow rate of $1 \mathrm{ml} / \mathrm{min}$. The injected volume was $25 \mu \mathrm{l}$ and the total time for analysis was $15 \mathrm{~min}$. The wavelengths of excitation and emission were 370 and $460 \eta \mathrm{m}$, respectively.

\section{Validation tests}

The method was validated for linearity, selectivity, specificity, recovery and precision (repeatability and reproducibility). To adequate the process to international and local legislation, National Health Surveillance Agency 
$(\mathrm{ANVISA})^{(10)}$, Foods and Drugs Administration (FDA) ${ }^{(6)}$ and Clinical and Laboratory Standards Institute $(\mathrm{CLSI})^{(2)}$ guidelines were followed.

\section{Results}

The fluorescent product of ALA was completely separated from the other fluorescent substances in the urine specimens (Figure).

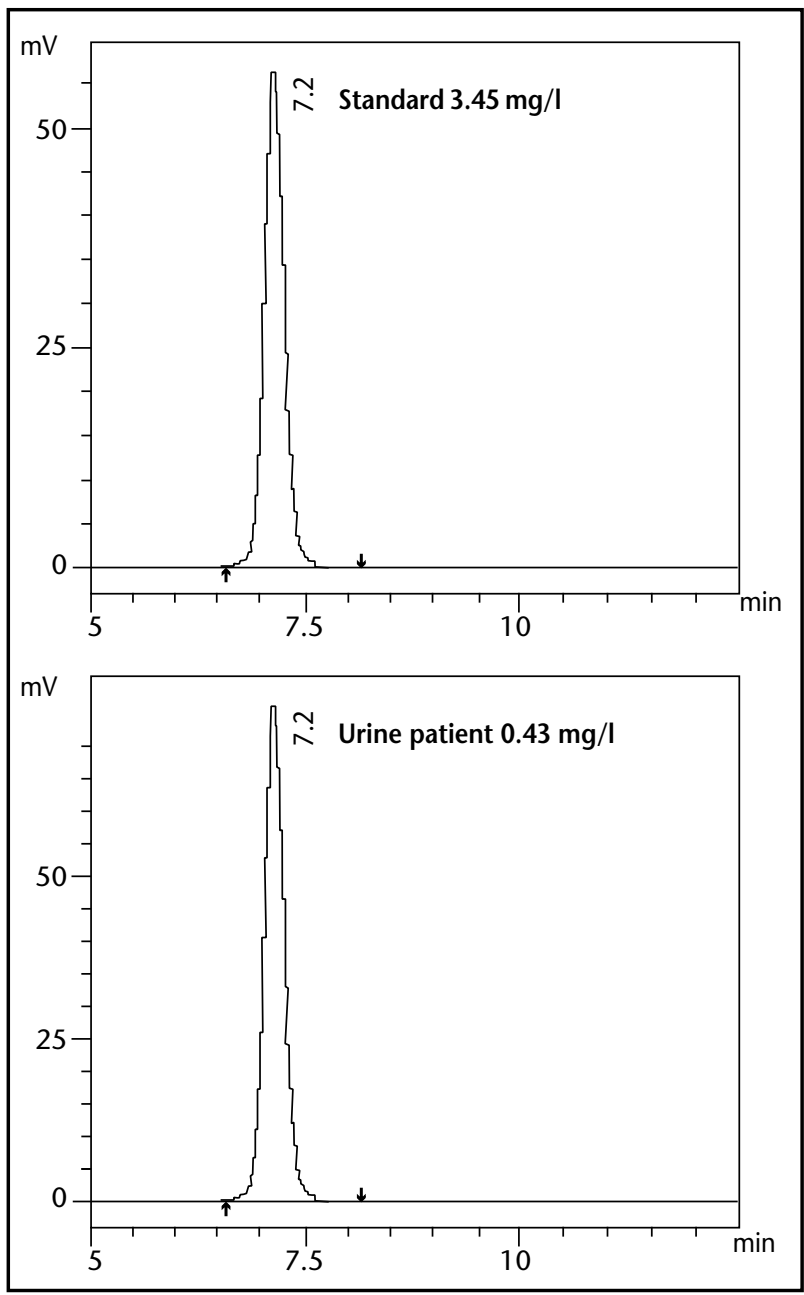

Figure - Chromatograms of $\delta$-aminolevulinic acid in standard solution $(3.45 \mathrm{mg} / \mathrm{l})$ and urine from a patient $(0.43 \mathrm{mg} / \mathrm{l})$ eluted near 7 minutes

The calibration study tested amounts of ALA in six different concentrations, varying from 0.02 to $9.6 \mathrm{mg} / \mathrm{l}$, in urine. The results show that concentrations tested were related to fluorescence intensities with a correlation coefficient of 0.99 . To examine the reproducibility of the ALA-U measurement, ALA standard concentrations were added to the pooled urine (Table).

The quantification limit was tested for a concentration of $0.04 \mathrm{mg} / \mathrm{l}$ of ALA and showed a within-run variation (CV)
Table Precision of assay using pooled urine

\begin{tabular}{ccc}
\hline $\begin{array}{c}\text { ALA concentration } \\
(\mathrm{mg} / \mathrm{l})\end{array}$ & $\begin{array}{c}\text { Intra-assay CV } \\
(\%)\end{array}$ & $\begin{array}{c}\text { Inter-assay CV } \\
(\%)\end{array}$ \\
5.3 & 2.9 & 1.3 \\
0.9 & 8.6 & 3.4 \\
0.3 & 3.0 & 0.9 \\
\hline
\end{tabular}

$A L A$ : $\delta$-aminolevulinic acid; $C V$ : within-run variation.

of $2.9 \%$. The recovery was tested with concentrations of 2.5, 2.7, and $3.5 \mathrm{mg} / \mathrm{l}$ of pooled urine, respectively and was found to range from $99 \%$ to $108 \%$.

To assess the stability of ALA-U, three urine samples (2.2, 1.5 and $2.3 \mathrm{mg} / \mathrm{l}$ ) were examined in four subsequent days in ambient temperature $\left(15-25^{\circ} \mathrm{C}\right)$, refrigerator $\left(2-8^{\circ} \mathrm{C}\right)$, and freezer $\left(\leq-8^{\circ} \mathrm{C}\right)$, respectively. After one day in ambient temperature, the concentrations were reduced from $18 \%$ to $22 \%$. In the other temperatures tested, a maximum $11 \%$ drop from the initial concentration was observed within four days. With respect to variations in the methanol concentration of the mobile phase, the best peak resolution of ALA was observed with $40 \%$ methanol.

From the 20 patients tested, 19 showed results of mean (m) plus standard (sd) deviation of $1.5 \pm 2.2 \mathrm{mg} / \mathrm{l}$ (range: 0.37-4.00), corresponding to $1.2 \pm 0.9 \mathrm{mg} / \mathrm{g}$ creatinine (range: 0.37-4.00), of ALA-U. One patient diagnosed with acute porphyria presented $17.3 \mathrm{mg} / \mathrm{g}$ creatinine of ALA-U.

\section{Discussion}

In this methodology, the results on precision ranged from 0.9 to 8.6 for the tested concentrations of $0.3-5.3 \mathrm{mg} / \mathrm{l}$. Other authors ${ }^{(12)}$ found a CV of $4 \%$ in intra-assay precision for a standard $1 \mathrm{mg} / \mathrm{l}$ of ALA. Endo et al. ${ }^{(5)}$ found recovery values of $99 \%$ to $106 \%$ and in the method studied ranged from $99 \%$ to $108 \%$.

Kondo et al. ${ }^{(9)}$ found mean ALA-U urinary levels of $0.76 \mathrm{mg} / \mathrm{l}$ ( $n=10$ healthy volunteers) and in this study we found $1.5 \mathrm{mg} / \mathrm{l}(n=19)$. Oishi et al. ${ }^{(11)}$, Endo et al. ${ }^{(5)}$ and this study found a $\mathrm{m} \pm \mathrm{sd}$ of $0.9 \pm 0.3(n=227$ exposed to $\mathrm{Pb}$, range: $0.30-2.85), 1.1 \pm 0.4$ ( $n=85$ not exposed to $\mathrm{Pb}$, range: $0.1-2.3)$ and $1.2 \pm 0.9 \mathrm{mg} / \mathrm{g}$ creatinine $(n=19$, range: $0.37-4.00)$, respectively.

The proposed methodology is adapted from HPLC methods with fluorescent detection developed by several researchers ${ }^{(11,12)}$. The advantages of using HPLC methodology has been extensively reported in the literature ${ }^{(7)}$. Colorimetric methods that also measure 
urinary ALA-like compounds, such as aminoacetone tend to obtain higher results in samples with an ALA concentration $<5 \mathrm{mg} / \mathrm{l}$. It is important to detect smaller variations of ALA-U concentrations with high sensitivity because of the possible preventive actions that can be applied.

This study improves the HPLC methodology by using fewer reagents, materials, and smaller volumes than others techniques tested avoiding wastes that contribute to environmental pollution. Results of validation show that the improved methodology is suitable for application in a routine laboratory to diagnose acute porphyria and help in the biological monitoring of $\mathrm{Pb}$ exposure. In addition, the method can also be adapted to detect ALA in plasma and other biological materials.

\section{References}

1. CALDEIRA, C. et al. Limits in the applicability of urine delta aminolevulinic acid determination as a screening test in the evaluation of occupational lead poisoning. Cad Saude Publica, v. 16, n. 1, p. 225-30, 2000.

2. CLINICAL AND LABORATORY INSTITUTE (CLSI). Evaluation of precision performance of clinical chemistry devices. Approved guideline - EP-5 A2. 2. ed., Wayne, 2006. (ISBN 1-56238-542-9)

3. DANIELL, W. E. et al. Chemical exposures and disturbances of heme synthesis. Environ Health Perspect, v. 105, n. 1, p. 37-53, 1997.

4. DUTRA, F.; BECHARA, E. J. E. Biochemistry and cytotoxicity of $\alpha$-aminoketones. Quim Nova, v. 28, n. 3, p. 483-91, 2005.

5. ENDO, Y. et al. Improvement of urinary delta-aminolevulinic acid determination by HPLC and fluorescence detection using condensing reaction with acetylacetone and formaldehyde. Sangyo Igaku, v. 36, n. 2, p. 49-56, 1994.

6. FOOD AND DRUG ADMINISTRATION (FDA). Validation of chromatographic methods. Available from: <http://www.fda.gov/CDER/GUIDANCE/cmc3.pdf>. Accessed in: jan. 2007.

7. FUKUI, Y. et al. Comparison of colorimetric and HPLC methods for determination of delta-aminolevulic acid in urine with reference to dose-response relationship in occupational exposure to lead. Ind Health, v. 3, n. 4, p. 691-8, 2005.

8. KAUPPINEN, R.; FRAUNBERG, M. V. U. Z. Molecular and biochemical studies of acute intermittent porphyria in 196 patients and their families. Clin Chem, v. 48, n. 11, p. 1891-900, 2002.

9. KONDO, M. et al. Direct injection method for quantification of delta-amminolevulinic acid in urine by highperformance chromatography. Chem Pharm Bull, v. 40, n. 7, p. 1948-50, 1992.

10. NATIONAL HEALTH SUVEILLANCE AGENCY (ANVISA). Guide for validation of analytical and bioanalytical methods. Available from: <http://anvisa.gov.br/hotsite/ genericos/legis/ resoluoes/475_02re_e.htm>. Accessed in: jan. 2007.

11. OISHI, $\mathrm{H}$. et al. Fluorometric HPLC determination of $\delta$-aminolevulinic acid (ALA) in the plasma and urine of lead workers: biological indicators of lead exposure. J Anal Toxicol, v. 20, p. 106-10, 1996.

12. TOMOKUNI, K. et al. Optimized liquid-chromatographic method for fluorometric determination of urinary $\delta$-aminolevulinic acid in workers exposed to lead. Clin Chem, v. 33, n. 9, p. 1665-7, 1987 